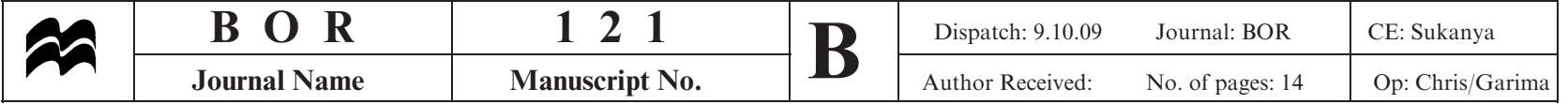

\title{
Late Quaternary glaciation and equilibrium line altitude variations of the McKinley River region, central Alaska Range
}

\author{
JASON M. DORTCH, LEWIS A. OWEN, MARC W. CAFFEE AND PHIL BREASE
}

\section{BOREAS}

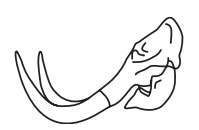

\begin{abstract}
Dortch, J. M., Owen, L. A., Caffee, M. W. \& Brease, P. 2009: Late Quaternary glaciation and equilibrium line altitude variations of the McKinley River region, central Alaska Range. Boreas, 10.1111/j.15023885.2009.00121.x. ISSN 0300-9483
\end{abstract}

Glacial deposits and landforms produced by the Muldrow and Peters glaciers in the McKinley River region of Alaska were examined using geomorphic and ${ }^{10} \mathrm{Be}$ terrestrial cosmogenic nuclide (TCN) surface exposure dating (SED) methods to assess the timing and nature of late Quaternary glaciation and moraine stabilization. In addition to the oldest glacial deposits (McLeod Creek Drift), a group of four late Pleistocene moraines (MP-I, II, III and IV) and three late Holocene till deposits (' $\mathrm{X}$ ', ' $\mathrm{Y}$ ' and ' $\mathrm{Z}$ ' drifts) are present in the region, representing at least eight glacial advances. The ${ }^{10} \mathrm{Be}$ TCN ages for the MP-I moraine ranged from $2.5 \mathrm{kyr}$ to $146 \mathrm{kyr}$, which highlights the problems of defining the ages of late Quaternary moraines using SED methods in central Alaska. The Muldrow ' $X$ ' drift has a ${ }^{10} \mathrm{Be}$ TCN age of $\sim 0.54 \mathrm{kyr}$, which is $\sim 1.3 \mathrm{kyr}$ younger than the independent minimum lichen age of $\sim 1.8 \mathrm{kyr}$. This age difference probably represents the minimum time between formation and early stabilization of the moraine. Contemporary and former equilibrium line altitudes (ELAs) were determined. The ELA depressions for the Muldrow glacial system were 560, 400, 350 and $190 \mathrm{~m}$ and for the Peters glacial system 560, 360, 150 and $10 \mathrm{~m}$, based on MP-I through MP-IV moraines, respectively. The difference between ELA depressions for the Muldrow and Peters glaciers likely reflects differences in supraglacial debris-cover, glacier hypsometry and topographic controls on glacier mass balance.

Jason M. Dortch (e-mail: Dortchim@uc.edu) and Lewis A.Owen (e-mail: lewis.owen@uc.edu),Department of Geology, University of Cincinnati, Cincinnati, OH 45220, USA; Marc W. Caffee (e-mail: Mcaffee@purdue.edu), Department of Physics, Purdue University, West Lafayette, IN 47907, USA; Phil Brease (e-mail: Phil Brease@nps.gov), Denali National Park and Preserve, P.O. Box 9, Denali Park, AK 99755, USA; received 2nd April 2009, accepted 27th August 2009.

Denali National Park, located in the central Alaska Range, contains the type locations for Alaskan glaciation (Reed 1961; Ten Brink \& Waythomas 1985) (Fig. 1). Yet the glacial history of this region is poorly defined, mostly because of the lack of appropriate methods and materials with which to date glacial landforms in this region. We characterize a region in the McKinley River area on the northern side of the Alaska Range to re-examine the glacial history of this region and to evaluate the applicability of ${ }^{10} \mathrm{Be}$ terrestrial cosmogenic nuclide (TCN) surface exposure dating (SED). We also calculate former equilibrium line altitudes (ELAs) for the major glacial advances to help elucidate the controls on glaciation. Using previous radiocarbon dating and lichenometry (Bijkerk 1980; Werner 1982) on late Holocene moraines, we assess how long moraines take to reach early stabilization after initial formation.

\section{Regional setting}

The Alaska Range is a large, convex north mountain belt stretching for $\sim 950 \mathrm{~km}$ and varying in width from $80 \mathrm{~km}$ to $200 \mathrm{~km}$. It was produced by the collision of an island-arc assemblage with the former North American continental margin, which has progressively deformed since the late Mesozoic (Ridgway et al. 2002; Eberhart-Phillips et al. 2003; Matmon et al. 2006). The relative relief is high
$(>5000 \mathrm{~m})$, rising from low forelands at $<1000 \mathrm{~m}$ above sea level (a.s.l.) to the highest peak in North America, Denali, at $6194 \mathrm{~m}$ a.s.1. This relief creates strong orographic effects and can help intensify storms (Thorson 1986). The northern side of the Alaska Range has a cold continental climate, while the southern side has a warmer maritime climate (Capps 1940). Much of the region is covered by temperate forest, peat bogs and taiga. The Cordilleran Ice Sheet covered the Alaska Range during the Late Wisconsinan, but its extent was limited on the northern slopes of the range. Accordingly, the glacial record is best preserved along the northern slopes of the Alaska Range (Wahrhaftig 1958; Hamilton \& Thorson 1983).

\section{Study area}

Our study focused on the McKinley River area, north of Mt. McKinley, in Denali National Park. This region contains numerous glaciers with associated moraines and sedimentary deposits providing evidence of multiple glaciations (Figs 1-3). The McKinley River area is of particular importance because it contains the type sections for the glacial geology of the central Alaska Range (Ten Brink \& Waythomas 1985).

The McKinley River area is bounded to the north by the Kantishna Hills, to the south by the Alaska Range, to the east by the foothills of the Alaska Range, and to the 


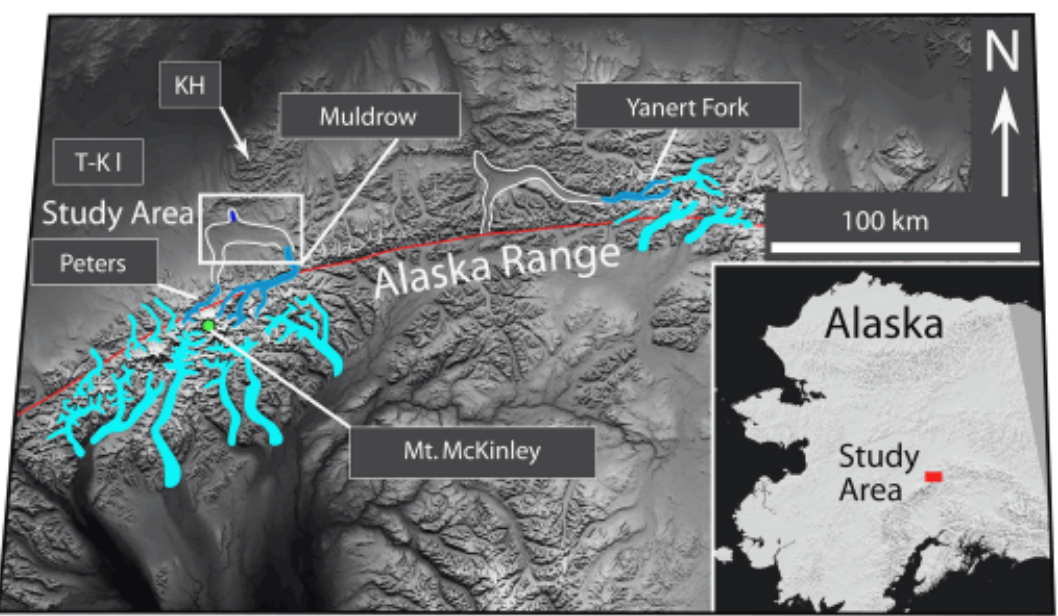

Fig. 1. Shuttle Radar Topography Mission (SRTM) hillshade image of the central Alaska Range. The Peters, Muldrow and Yanert Fork glaciers are highlighted in dark blue with white lines outlining their maximum extent during the local last glacial maximum. Other major active glaciers are marked in light blue. The red line shows the trace of the Denali Fault. $\mathrm{KH}=$ Kantishna Hills; $\mathrm{T}-\mathrm{Kl}=$ Tanana-Kuskokwin lowland. Inset is SRTM hillshade of Alaska (U.S. Geological Survey 2007). DEM data from CGIAR-CSI. west by the Tanana-Kuskokwin lowland. The McKinley River area contains numerous kettlehole lakes and is covered with dense taiga. The taiga is typically $0.5-1.0 \mathrm{~m}$ tall, which in many places completely covers moraines. Lower areas in the McKinley River area contain patches of temperate forest. The annual precipitation is $\sim 360 \mathrm{~mm}$, occurring mostly during the summer months; however, snowfall occurs throughout the year on the high peaks in the Alaska Range (Werner 1982).

Glacial deposits in this region were first described by Capps (1932). The Late Wisconsinan glacial limit in the McKinley River area was initially mapped by Reed (1933, 1961) and later by Ten Brink \& Waythomas (1985), Thorson (1980) and Werner (1982). These researchers assign the glacial landforms to 10 glacial stages in the McKinley River area; stages representing multiple advances of the Muldrow and Peters glaciers.
We adopt the terminology of Ten Brink \& Waythomas (1985) and Werner (1982), and focus on late Quaternary moraines produced by the Muldrow and Peters glaciers (Werner 1982; Werner \& Child 1995) (Fig. 2). Radiocarbon and lichenometry ages have been obtained for the late Quaternary moraines in this region (Werner 1982; Ten Brink \& Waythomas 1985). Briner \& Kaufman (2008) reviewed the Late Pleistocene glacial chronologies in Alaska and summarized the available data for the Alaska Range. Their analysis indicates that the Late Pleistocene glaciers retreated from their terminal positions at $\sim 25-27 \mathrm{kyr}$ in arctic Alaska and $\sim 19-22$ kyr in southern Alaska.

Using topographic expression and physiographic setting, Reed (1961) argued that moraines in the McKinley River region, which he called the McKinley Park (MP) moraines, formed two distinct sets (MP-I

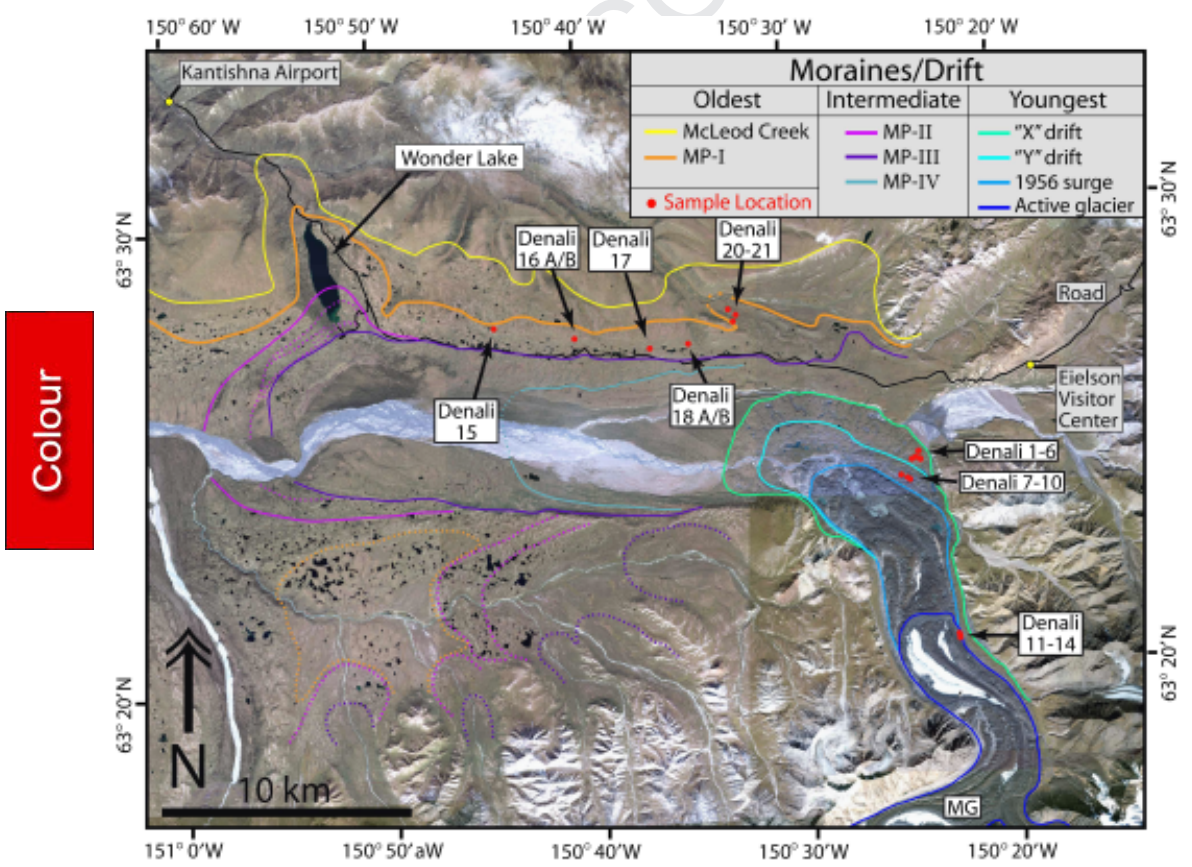

Fig. 2. IKONOS image of the Wonder Lake area showing the McKinley River and the extent of glacial stages (modified from Werner \& Child 1995) and SED sample locations. The dashed lines show the moraines that were not investigated in the field. MP $=$ McKinley Park moraines; $\mathrm{MG}=$ Muldrow Glacier. IKONOS image courtesy of Denali National Park. The terminology for the moraines and drift units is taken from Ten Brink \& Waythomas (1985) and Werner (1982). 

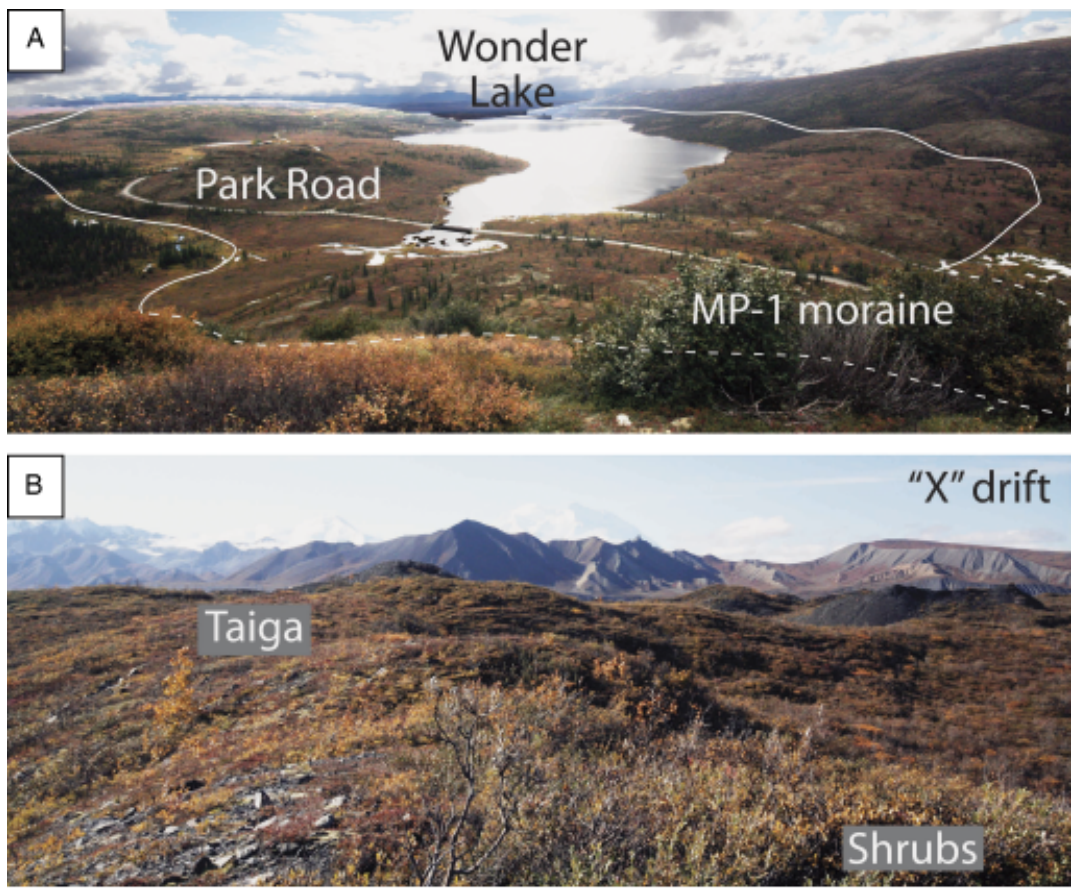

Fig. 3. Views of the McKinley Park and late Holocene moraines. A. Southern view of Wonder Lake and the hummocky MP-I moraine. B. Southern view of the ' $\mathrm{X}$ ' drift moraine. C. Northwest view of a ' $Y$ ' drift ice-wall. Dense taiga and tundra cover all stable moraines, making their morphology difficult to see. Dashed lines mark glacial limits obscured by vegetation or distance.

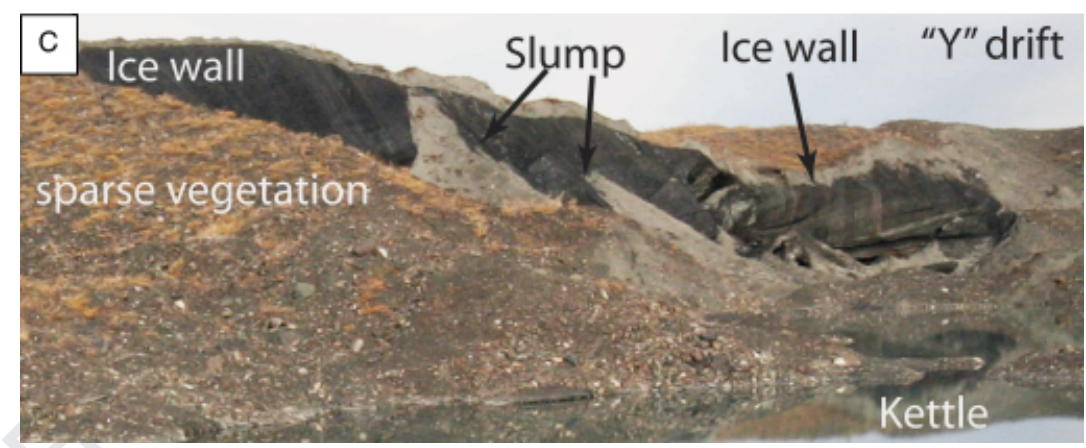

and II and MP-III and IV) based on geomorphic characteristics, and he correlated these with moraines in all major valleys in the central Alaska Range. Werner \& Child (1995) hypothesize that the MP-I to IV moraines represent four separate advances during the Late Pleistocene and that they correlate with two periods of climatic deterioration that led to full glacial conditions. The MP-I moraine has been dated using radiocarbon methods to between $28.0 \pm 0.3 \mathrm{kyr}$ and $19.5 \pm 0.5 \mathrm{kyr}$ (Ten Brink \& Waythomas 1985; all radiocarbon ages were calibrated using CalPal-online). Harrison (1969, 1970) and Werner (1982) recognized three late Holocene till deposits, ' $\mathrm{X}$ ', 'Y' and ' $\mathrm{Z}$ ' drifts, and the 1956 till deposit. The 1956 till deposit formed during the 1956 surge of the Muldrow Glacier.

The 1956 surge deposit and the oldest glacial deposits (McLeod Creek drift) in this region were not examined in our study. Harrison $(1969,1970)$, Ten Brink \& Waythomas (1985), Thorson (1980) and Werner (1982) have provided more details on these deposits.

Using lichenometry on Rhizocarpon geographicum and Rhizocarpon alpicola, Werner (1982) estimated the age of the ' $\mathrm{X}$ ' and ' $\mathrm{Y}$ ' drifts to be $1.8+0.0 /-0.1 \mathrm{kyr}$ and $0.9+0.0 /-0.1 \mathrm{kyr}$, respectively. Werner (1982) used a growth curve developed by Denton \& Karlén (1973a, b, 1977) for the Wrangell and St. Elias mountains for agedetermination in the central Alaska Range. Bijkerk (1980) demonstrated that the Denton \& Karlén (1973a, b, 1977) lichen growth curve for the White River valley was applicable for the lichens in the McKinley River area. Denton \& Karlén (1973a, b, 1977) used two control points from mining waste of known age and a single control point determined by radiocarbon dating on organic material from $15 \mathrm{~cm}$ below a peat bog located in an icemarginal drainage in the Foraker Valley. Bijkerk (1980) argued that the White River valley and the McKinley River region were geographically close with similar continental climates.

Rampton (1978) replaced control point 12 on Denton \& Karlén's (1973a, b, 1977) growth curve with his own calibrated lichen point from the White River valley in the St. Elias Range. Replacement of the control point increases the slope of the lichen curve, resulting in an overestimate of lichen ages by $\sim 100$ years for lichen diameters between 


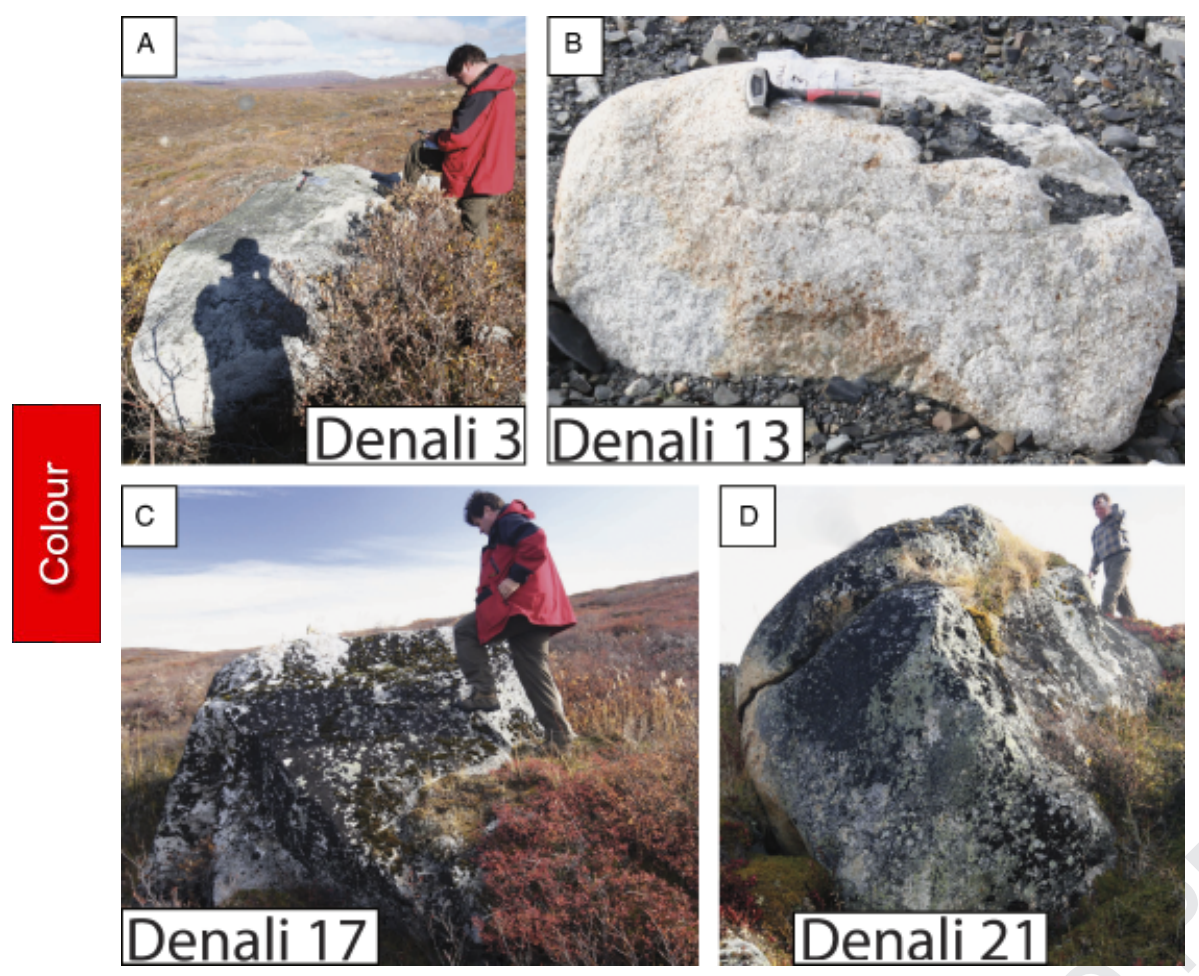

Fig. 4. Views of boulders sampled for cosmogenic radionuclide surface exposure dating. A. Granitic boulder on the 'X' drift landform. B. Granitic boulder with patches of supraglacial debris on the active ice of the Muldrow Glacier. C. and D. Large granitic boulders on the MP-I moraine.
40 and $120 \mathrm{~mm}$.In addition, Bull \& Brandon (1998) and Winchester \& Harrison (2000) argued that there could be an up to 5-year and 13-year time-lag between moraine deposition and initiation of lichen growth, respectively. We therefore favour the original Denton \& Karlén (1973a, b, 1977) growth curve, but include the possible overestimation of ages by $\sim 100$ years in the lichen ages error $(+0.0 /-0.1 \mathrm{kyr})$.

\section{Methods}

\section{Mapping}

The moraines mapped by Werner (1982) in the McKinley River area were examined and remapped in the field, aided by aerial photography, topographic maps generated from $90 \mathrm{~m}$ resolution Shuttle Radar Topography Mission (SRTM) digital elevation models (DEMs) and IKONOS imagery provided by Denali National Park (CGIAR-CSI 2007). The extent of the contemporary headwall of the Muldrow and Peters glaciers was determined using NASA Worldwind false colour imagery and plotted onto SRTM DEM in ArcGIS 9.1. Surface area and hypsometry of the glaciers were measured using the DEM by applying ArcGIS 9.1 3D Analyst and ReadArcGrid, respectively (Nash 2007).

\section{${ }^{10}$ Be dating}

Samples were collected for ${ }^{10} \mathrm{Be}$ dating by chiselling $\sim 250 \mathrm{~g}$ of rock from the upper $5 \mathrm{~cm}$ of granitic boulders on moraines (Fig. 4). Large boulders ( $>1 \mathrm{~m}$ high) were preferentially sampled to reduce possible shielding by snow or former loess cover. More than four ${ }^{10} \mathrm{Be}$ samples were collected from granitic boulders on each moraine from sites that showed the least evidence of erosion, deflation, cryoturbation or melting. Multiple samples on each moraine allow statistical analysis of age populations and examination of landform stabilization processes (landform denudation, exhumation and toppling) to be assessed. The location, geomorphic setting, size, shape and weathering characteristics of each sampled boulder were recorded (Table 1). The inclination from the boulder surface to the surrounding horizon was measured to quantify topographic shielding.

Samples were crushed and sieved to obtain a 250 $500 \mu \mathrm{m}$ size fraction. This was followed by four acid leaches: aqua regia for $>9 \mathrm{~h}$, two $5 \% \mathrm{HF} / \mathrm{HNO}_{3}$ leaches for $\sim 24 \mathrm{~h}$ and one $1 \% \mathrm{HF} / \mathrm{HNO}_{3}$ leach for $24 \mathrm{~h}$. Lithium heteropolytungstate heavy liquid separation was applied after the first $5 \% \mathrm{HF} / \mathrm{HNO}_{3}$ leach. Atomic absorption spectrometry (AAS) low-background Be carrier $\left({ }^{10} \mathrm{Be} /{ }^{9} \mathrm{Be}\right.$ of $\left.\sim 1 \times 10^{-15}\right)$ was added to the pure quartz. The quartz was dissolved in $49 \% \mathrm{HF}$ and passed through anion and cation exchange columns along with chemical blanks to extract $\mathrm{BeO}$. The $\mathrm{BeO}$ was oxidized through ignition at $750^{\circ} \mathrm{C}$ and mixed with $\mathrm{Nb}$ powder and loaded in steel targets for measurement of the ${ }^{10} \mathrm{Be} /{ }^{9} \mathrm{Be}$ ratios by accelerator mass spectrometry (AMS). AMS measurements were taken at the Purdue Rare Isotope Measurement (PRIME) Laboratory at Purdue University. 


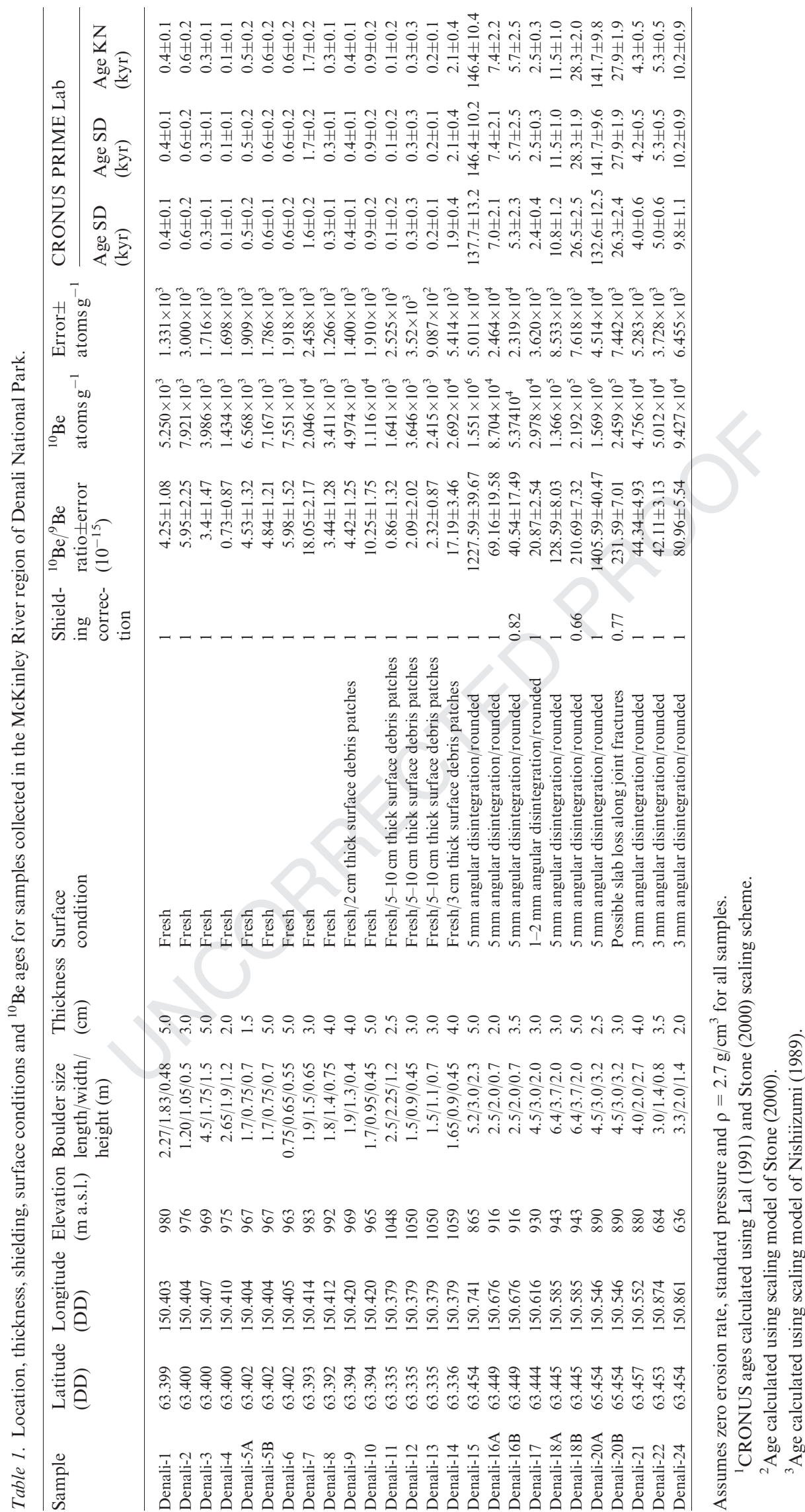




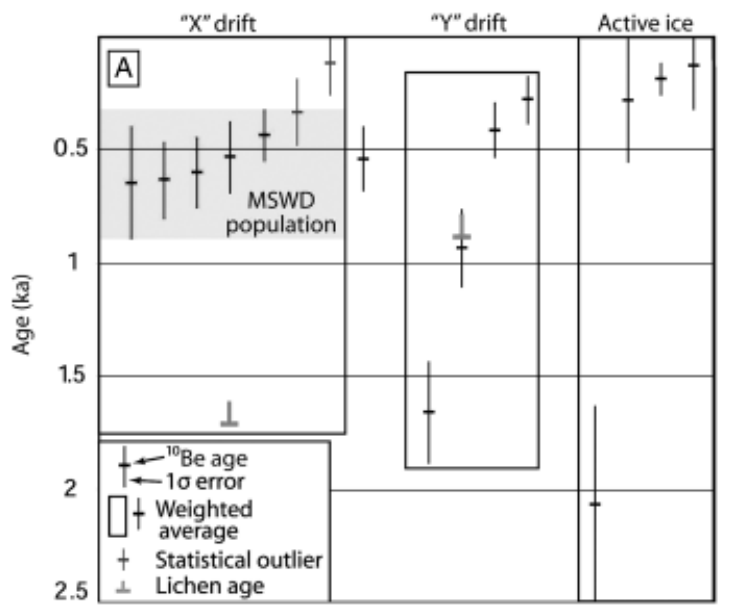

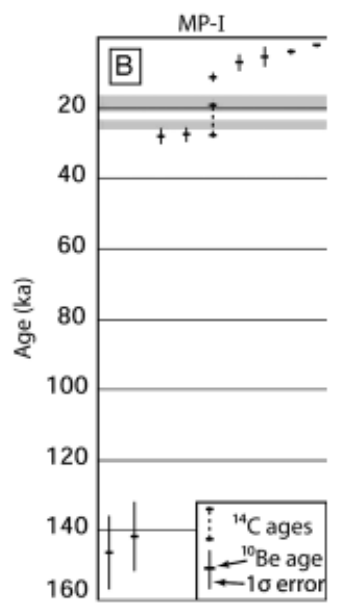

Fig. $5 .{ }^{10} \mathrm{Be}$ age plot with ages arranged in descending order grouped by landform. A. ${ }^{10} \mathrm{Be}$ ages for late Holocene moraines. Lichen ages (grey) have a negative error only. B. ${ }^{10} \mathrm{Be}$ ages of the MP-I moraine. Briner et al.'s (2005) two phases of regional glaciation during the local last glacial maximum are highlighted by thin light-grey bars. Age bracketing radiocarbon ages are connected by a dashed line.
AMS at the PRIME Laboratory was calibrated using KN Standard Be 0152 with a ${ }^{10} \mathrm{Be} /{ }^{9} \mathrm{Be}$ ratio of $8558 \times 10^{-15}$. Three chemical blanks were measured and resulted in an average ${ }^{10} \mathrm{Be} /{ }^{9} \mathrm{Be}$ ratio of $0.41 \pm$ $0.21 \times 10^{-15}($ error $=1 \sigma)$. Ages were calculated using the PRIME Laboratory Rock Age calculator with the scaling factors of Stone (2000), a sea-level low-latitude production rate of $4.5 \pm 0.3{ }^{10} \mathrm{Be}$ atoms/g of quartz/year and a ${ }^{10} \mathrm{Be}$ half-life of $1.36 \mathrm{Myr}$ (Table 1) (cf. Nishiizumi et al. 2007; PRIME Laboratory 2007). Ages were also calculated using the CRONUS calculator and Stone (2000) scaling schemes reported in Table 1 for comparison.

Corrections for geomagnetic field variation were not made due to the ongoing debate regarding which correction factors are the most appropriate. At this high latitude, however, corrections for variations in the geomagnetic field are small. For example, the oldest boulder, Denali 15 , has a ${ }^{10} \mathrm{Be}$ age of $137.7 \pm 13.2 \mathrm{kyr}$; uncorrected for geomagnetic variation using the scaling scheme of Lal (1991) and Stone (2000). Using the scaling model of Nishiizumi et al. (1989) would result in a ${ }^{10} \mathrm{Be}$ age of $146.4 \pm 10.4 \mathrm{kyr}$; a difference in age of $6.3 \%$. However, owing to the systematic nature of geomagnetic variability, corrections would not likely affect correlation of landforms in adjacent areas, such as the Wonder Lake area and Nenana River Valley. We refer the reader to Balco et al. (2008) for more details. Ages are not corrected for boulder surface erosion because the effect is small on young landforms; on older landforms there is certainly erosion, but it is difficult to quantify. However, a boulder weathered at a maximum rate of $4.0 \mathrm{~m} / \mathrm{Myr}$ (calculated from the oldest boulder, Denali 15) in our study area using the method of Lal (1991), for example, with a calculated age of $10 \mathrm{kyr}$, would underestimate the true age by $\sim 4 \%$.

The mean square of weighted deviates (MSWD) method of McDougall \& Harrison (1999) is used to assess whether ${ }^{10}$ Be SED ages statistically represent a single population. In this method, outliers are removed iteratively from the data set until the MSWD is $<1$. Where the $1 \sigma$ error of a population overlaps, we use the weighted mean and error $\left(\mathrm{M}_{\mathrm{w}}\right)$ of the population to define the ages of landforms (Fig. 5).

\section{Contemporary and former ELAs}

Calculating contemporary and former ELAs is complex and numerous methods are available. These include the area accumulation ratio (AAR), toe to headwall ratio (THAR), area altitude (AA) and area altitude balance ratio (AABR) (Benn \& Lehmkuhl 2000; Benn et al. 2005; Osmaston 2005). Glacier morphology (debriscover, surface area, complex tributaries), relief of valley sides, catchment area and shape and aspect can have a significant effect on the ELA of a glacier and what appropriate method should be used to calculate the ELA.

The AAR, THAR, AA and AABR methods and issues regarding their use and accuracy are described in detail in Benn \& Lehmkuhl (2000), Benn et al. (2005) and Owen \& Benn (2005). Benn et al. (2005) and Owen \& Benn (2005) suggest that several methods should be applied and that the most regionally consistent be used to quantify ELAs and ELA depressions ( $\triangle$ ELAs). Therefore, we provide ELA values using the change from convex to concave glacier surface, the AAR (with values of $0.4,0.5$ and 0.6 ), the THAR (0.5), the AA and the AABR methods (Table 2). We average the most consistent methods and use a $1 \sigma$ standard error to define contemporary and former ELAs.

To reconstruct the size and shape of former glaciers, we used the moraines produced during each glacial advance to mark the extent of the former glacier trunk terminus. The contemporary tributary glacial system was extrapolated downvalley to the former terminus. The calibrated AABR model can then aid in determining former ELAs. Extrapolation of the tributary glacial system, however, can lead to an overestimation of the glacial system. We, therefore, used an iterative process 
whereby tributary valleys that do not contain the modelled ELA were not used in the reconstruction. That is, these tributary valleys would not have accumulation zones, and glaciers would not be able to form in them. This iterative process is repeated until the glacial system and modelled AABR ELAs are in balance.

\section{Landform descriptions}

\section{MP-I moraine}

The MP-I moraine is a prominent $70 \mathrm{~km}$ long, nearly continuous ridge with numerous kettleholes. It is located on the northern side of the Park Road, which encompasses Wonder Lake (Fig. 2). The moraine is covered by taiga in most areas. A gravelly surface derived from till is present where the moraine crest has been deflated (Fig. 3A). The MP-I moraine terminus is located southwest of Wonder Lake $\sim 40 \mathrm{~km}$ from Muldrow Glacier. Thorson (1980) and Werner (1982) suggest that the moraine was produced when the Muldrow and Peters glaciers joined to form a broad piedmont glacier lobe on the McKinley River lowlands.

The timing of the onset of glaciation that produced the MP-I moraine is defined by a radiocarbon age of $28.0 \pm$ $0.3 \mathrm{kyr}\left(24900 \pm 200{ }^{14} \mathrm{C}\right.$ yr) onsoil organics in the Little Delta River Valley (Ten Brink \& Waythomas 1985). Correlative glacial stages in the Grestle River and Tanana valleys have similar ages at $28.7 \pm 0.9 \mathrm{kyr}(25800 \pm 950$ ${ }^{14} \mathrm{C}$ yr $)$ and $28.7 \pm 0.8 \mathrm{kyr}\left(25800 \pm 800{ }^{14} \mathrm{C} \mathrm{yr}\right)$, respectively (Fernald 1965; Hamilton 1976). These radiocarbon ages and SED elsewhere in Alaska by Briner et al. (2005) and Briner \& Kaufman (2008) suggest that regional glaciation during the last glacial started at $\sim 28 \mathrm{kyr}$.

The end of the glacial advance that produced the MP-I moraine is defined by organic rich pond silt in MP-I outwash in the McKinley Valley that is dated to $19.5 \pm 0.5 \mathrm{kyr}$ $\left(17800 \pm 290{ }^{14} \mathrm{C}\right.$ yr) (Ten Brink \& Waythomas 1985). The MP-I outwash was overridden by a short-lived MP-I re-advance with glacial retreat beginning soon after $\sim 19.5$ kyr (Ten Brink \& Waythomas 1985).

There are few boulders on the MP-I surface, but those that are present range in size from $<1 \mathrm{~m}$ to $>6 \mathrm{~m}$ and are composed of granite. Nine samples were collected for ${ }^{10} \mathrm{Be}$ dating from the six largest and most stable boulders that exhibited the least evidence of erosion (Denali 15-18, 20-21) (Fig. 4C, D). Duplicate samples (Denali 16B, 18B and 20B) were collected from three of the boulders to check for possible loss of significant rock thickness along fractures due to physical weathering such as frost wedging.

\section{$M P-I I, I I I$ and IV moraines}

No samples were collected for dating from the MP-II, III and IV moraines because of the lack of suitable 
boulders; these moraines are not described in detail. The MP-II, III and IV moraines are used as limits for ELA reconstructions.

\section{Muldrow ' $X$ ' drift}

The ' $\mathrm{X}$ ' drift is $\sim 1 \mathrm{~km}$ wide and is located $\sim 12 \mathrm{~km}$ from the Muldrow Glacier. It is composed of several small discontinuous moraine ridges with numerous kettleholes. Reed (1961) described the 'X' drift as recent and suggested that it formed a few hundred years ago. Werner (1982) described this deposit as massive unstratified till with a hummocky surface lacking distinct constructional recessional ridges.

There is no evidence of active slumping in the ' $\mathrm{X}$ ' drift. No streams originate from the drift and no exposed icewalls are present, but this does not preclude the possibility that ice-cores exist within the drift. A thick vegetative mat and small bushes are present on the drift, making the moraine stable (Fig. 3B). To account for the ice-core and lack of distinct moraines, Werner (1982) argued that this deposit formed during a glacier surge.

Werner (1982) estimated the age of the ' $\mathrm{X}$ ' drift to be $1710 \mathrm{yr} \mathrm{BP}$ based on the largest lichen diameter $(90 \mathrm{~mm})$. This is a minimum estimate, because the five largest lichens $(79$ to $90 \mathrm{~mm}$ ) were dead. Unfortunately no error analysis was reported for the lichenometry ages established by Werner (1982). We use an age of $1768 \mathrm{yr}$ BP corrected to 2008 to make the lichen age directly comparable to ${ }^{10} \mathrm{Be}$ ages (i.e. $1.8+0.0 /-0.1 \mathrm{kyr}$ ), since the ${ }^{10} \mathrm{Be}$ ages are referenced to the date that the samples were measured. The age will be $\sim 95$ years younger if adjusted for Rampton's (1978) control point.

Boulders on the surface of the ' $\mathrm{X}$ ' drift are composed of granite and foliated schist. Only granitic boulders were sampled to limit potential sources of error and to avoid comparison between different lithologies that might weather at different rates. The sampled boulders ranged in size from 0.75 to $4.5 \mathrm{~m}$. Seven samples were collected from six boulders (Denali 1-6) with hard fresh surfaces (Fig. 4A).

\section{Muldrow ' $Y$ ' drift}

The ' $\mathrm{Y}$ ' drift ranges from 0.5 to $2.0 \mathrm{~km}$ wide and is located $\sim 11 \mathrm{~km}$ from Muldrow Glacier (Fig. 2). The drift is composed of poorly preserved segmented moraine ridges and can be traced upvalley on both sides of the Muldrow Glacier valley (Werner 1982). On the basis of the presence of active slumping, streams originating from outcrops and several outcrops of glacial ice, Werner (1982) argued that the ' $Y$ ' drift was unstable (Fig. 3C). We concur with this view, especially since the surface has modest vegetative cover and numerous kettleholes.

Based on the largest lichen diameter $(60 \mathrm{~mm})$, Werner (1982) argued that the ' $\mathrm{Y}$ ' drift had an age of $\sim 826$ years BP $(0.9+0.0 /-0.1 \mathrm{kyr}$ before 2008$)$. The age will be $\sim 92$ years younger if adjusted for the Rampton (1978) control point.

Four samples (Denali 7-10) were collected from four boulders (ranging in length from 1.7 to $1.9 \mathrm{~m}$ ) for ${ }^{10} \mathrm{Be}$ dating. Three of the boulders that were sampled (Denali 7-9) had a thin $(<2 \mathrm{~cm})$ veneer of supraglacial debris on some of their upper surfaces. The ${ }^{10} \mathrm{Be}$ samples were collected from raised boulder surfaces to avoid possible shielding by the debris.

\section{Active ice}

The active ice on Muldrow Glacier is covered by supraglacial debris that is mostly $>1 \mathrm{~m}$ thick, but there are also bare glacial ice zones, exposed ice-walls and small supraglacial lakes. The glacier surface is hummocky and there are many ridges composed of supraglacial debris (sand up to $5.0 \mathrm{~m}$ boulders).

Denali samples 11-14 were collected from boulders that had thin (a few centimetres thick) till debris in surface depressions and glacial striations. Samples were collected from raised surfaces on the boulders to avoid potential shielding of cosmic rays by the debris-cover (Fig. 4B). These boulders were devoid of lichen.

\section{Stabilization of landforms}

TCN surface exposure ages are influenced by many factors, some geologic and others having to do with the physics of TCN production (Briner et al. 2001, 2005; Gosse \& Phillips 2001; Owen et al. 2008). These include uncertainty associated with calculating the production rate of TCNs, including scaling for geomagnetic variation, elevation and latitude, topographic shielding, sample thickness and density. The total uncertainty associated with these factors is usually $\leq 10 \%$ of the SED age and is discussed in more detail in Balco et al. (2008).

Among the geologic factors influencing the production of TCN is the inheritance of TCNs by prior exposure of boulders or rock surfaces, shielding by sediment and/or snow, exhumation and weathering. These problems have been described in detail in numerous studies (Hallet \& Putkonen 1994; Gosse \& Phillips 2001; Putkonen \& Swanson 2003; Putkonen \& O'Neil 2005; Balco et al. 2008; Owen et al. 2008; Putkonen et al. 2008). In addition to these geologic uncertainties, there are those specifically associated with glacial landforms. Moraine surfaces, in particular, are unstable, especially as ice-cores melt and as their steep slopes collapse by mass movement processes, both during and after deglaciation, before the moraines stabilize (Briner et al. 2005; Zech et al. 2005; Putkonen et al. 2008). For clarity of discussion, we define the following periods: (1) moraine formation - the end of deposition and the beginning of deglaciation; (2) early 
1 stabilization - the rapid readjustment of a moraine to 2 the angle of repose or subsidence caused by the melting 3 of an ice-core; and (3) middle to late phase stabilization 4 - slow but continual readjustments of a moraine in re5 sponse to denudation and weathering. ice-core from direct solar radiation. Mattson et al. (1992) showed that glacial ice melts at a rate of $\sim 110 \mathrm{~mm}$ /day with $10 \mathrm{~mm}$ of debris-cover, whereas a critical debriscover thickness of $\geq 400 \mathrm{~mm}$ almost causes ablation to cease in the Himalaya. This could potentially make sublimation rates key in the melting of an ice-core where debris-cover is thick (>400 mm). However, Nakawo \& Rana (1999) show that debris-free ice cliffs totalling 2\% surface area ablate 12 times faster than debris-covered ice. They suggest that kettles and supraglacial lakes have a similar effect. The debris-cover is $\geq 1 \mathrm{~m}$ thick on the ' $\mathrm{X}$ ' and ' $\mathrm{Y}$ ' drifts and active ice. Ice cliffs and kettles were present only on the ' $\mathrm{Y}$ ' drift. As shown in Fig. 3C, the exposed ice-cliff contains debris, which causes the ice to potentially melt at $\sim 110 \mathrm{~mm} /$ day. Ice-cliffs were likely present on the ' $\mathrm{X}$ ' drift in the past and probably played a more significant role in melting of the ' $\mathrm{X}$ ' drift ice-core than sublimation.

The time-lag between formation and early stabilization of moraines has received little attention, yet TCN ages can provide important insights into early moraine stabilization, especially when used in conjunction with other methods. Boulders with both lichen and ${ }^{10} \mathrm{Be}$ SED ages likely moved during the early stabilization period. However, lichenometry has the advantage of measuring lichens on all exposed sides of a boulder during development of the growth rate calibration curve. Therefore, changes in growth rate from boulder movement are accounted for in the calibration of the growth-rate curve. When considering TCN SED ages, the concentration in a given sample integrates over the entire exposure geometry of the sample. So, if a boulder rolled, the measured ${ }^{10} \mathrm{Be}$ SED age would underestimate the true age. While the lichen growth rate is affected by boulder movement, all sides of a boulder are taken into account and the calibrated lichen ages are therefore not as significantly affected as the SED ages. We suggest that lichens more accurately represent a minimum age of final deposition, while SED more accurately reflects a minimum age of early stabilization. Quantifying this time-lag is essential for understanding and correlation of Holocene glacial succession defined by SED methods.

Middle to late moraine stabilization was initially investigated by Hallet \& Putkonen (1994), who showed that moraines degrade and expose fresh boulders over time. We refer the reader to Zreda \& Phillips (1994), Putkonen \& Swanson (2003), Putkonen \& O'Neil (2005), Zech et al. (2005), Smith et al. (2005), Barrows et al. (2007, 2008), Applegate et al. (2006, 2008), Applegate \& Alley 2007, Putkonen et al. (2008) for more information, as this study focuses on early stabilization.

\section{MP-I moraines}

${ }^{10} \mathrm{Be}$ ages on the MP-I moraine range from $2.5 \mathrm{kyr}$ to $146 \mathrm{kyr}$ (Fig. 5). These ages do not cluster well and do not pass the MSWD test (McDougall \& Harrison 1999). The MP-I glacial stage was defined by radiocarbon ages to have started by $28.0 \pm 0.3 \mathrm{kyr}$ and finished shortly after $19.5 \pm 0.5 \mathrm{kyr}$. Two boulders (Denali 15 at $146.4 \pm 10.2 \mathrm{kyr}$ and Denali $20 \mathrm{~A}$ at $141.7 \pm 9.8 \mathrm{kyr})$ are significantly older than the accepted $28.0 \pm 0.3 \mathrm{kyr}$ based on radiocarbon dating. The Delta moraine in the Delta River Valley, bracketed between $140 \pm 10$ and $190 \pm 20 \mathrm{kyr}$, was produced by the Black Rapids, Canwell, Fels and Castner glaciers coalescing and advancing $\sim 80 \mathrm{~km}$ from their present terminus (Begét \& Keskinen 2003). The Lignite Creek moraine in the Nenana River valley has a limiting age of $\leq 181 \pm 19 \mathrm{kyr}$ and is correlated with the Delta glacial stage on (Begét \& Keskinen 1991; Begét 2001). Owing to the overlap in ages and the proximity of the areas, we attribute the old exposure ages of Denali 15 and Denali 20A to inheritance. However, inadequate age control on glacial landforms older than the MP-1 moraine prevents identification of the origin of these boulders.

Other samples (Denali 16A, 16B, 17, 18A and 21 at $7.4 \pm 2.2 \mathrm{kyr}, \quad 5.7 \pm 2.5 \mathrm{kyr}, 2.5 \pm 0.3 \mathrm{kyr}, \quad 11.5 \pm 1.0 \mathrm{kyr}$ and $4.3 \pm 0.5 \mathrm{kyr}$, respectively) are significantly younger than the bracketing radiocarbon ages. These boulders have probably been exhumed or toppled since moraine deposition. Two ages, $28.3 \pm 2.0 \mathrm{kyr}$ (Denali 18B) and $27.9 \pm 1.9 \mathrm{kyr}$ (Denali 20B), overlap with the radiocarbon ages (Fig. 5B), while another age is significantly older (Denali 20A at 141.7 $\pm 9.8 \mathrm{kyr}$ ). The divergence in the ages and dominance of young ages indicates that erosion of boulders likely dominates its TCN concentration.

\section{Muldrow ' $X$ ' drift}

The ${ }^{10} \mathrm{Be}$ ages on the ' $\mathrm{X}$ ' drift range from $0.1 \pm 0.1 \mathrm{kyr}$ to $0.6 \pm 0.2 \mathrm{kyr}$ (Fig. 5). MSWD analysis identified two young outliers (Denali 3 and 4 ) and a strong population of five ${ }^{10} \mathrm{Be}$ ages with $1 \sigma$ error overlap and a weighted mean of $0.54 \pm 0.14 \mathrm{kyr}$. The two young outliers are probably due to recent exhumation or toppling. Boulder weathering is unlikely to affect the age, since the ' $\mathrm{X}$ ' drift is young. The weighted mean is interpreted to represent stabilization of the ' $\mathrm{X}$ ' drift moraine.

Using ${ }^{10} \mathrm{Be},{ }^{26} \mathrm{Al},{ }^{36} \mathrm{Cl},{ }^{21} \mathrm{Ne}$ and previous radiocarbon ages, Ivy-Ochs et al. (2006, 2008) have suggested that the Gschnitz Stadial in the European Alps accumulated at $\sim 17 \mathrm{kyr}$, but that moraines reached stabilization at $\sim 15.4 \mathrm{kyr}$. Moreover, Briner et al. (2005) argued that moraines reach early stabilization some time after deglaciation in Alaska. Here, the minimum lichen age $(1.8+0.0 /-0.1 \mathrm{kyr})$ of Werner (1982) and the stability of the ' $X$ ' drift enables the time 
between moraine formation (lichen age) and early stabilization $\left({ }^{10} \mathrm{Be}\right.$ weighted mean) to be estimated at 1.26 $+0.14-0.24 \mathrm{kyr}$. This $\sim 1.3 \mathrm{kyr}$ early moraine stabilization period is a minimum, because the measured lichens are dead and therefore might not represent the true age of the ' $\mathrm{X}$ ' drift; furthermore, there may be a lag of $2.5-13$ years in initiation of lichen growth. The $\sim 1.3 \mathrm{kyr}$ early moraine stabilization estimate is comparable to the $\sim 1.6 \mathrm{kyr}$ stabilization period of Ivy-Ochs et al. (2008). This time-lag is significant when comparing and correlating late Holocene landforms between areas and when using methods such as optically stimulated luminescence, TCN and radiocarbon dating.

\section{Muldrow ' $Y$ ' drift}

The four ${ }^{10} \mathrm{Be}$ ages on the ' $\mathrm{Y}$ ' drift range from $0.3 \pm 0.1 \mathrm{kyr}$ to $1.6 \pm 0.2 \mathrm{kyr}$ (Fig. 5). These ages do not pass MSWD analysis, which is characteristic of a landform that is unstable or actively being eroded. The bare glacial ice-walls, springs originating from till exposures and active slumping indicate that the ' $\mathrm{Y}$ ' drift is still unstable. The large range of ages reflects the instability of the ' $Y$ ' drift.

The ' $Y$ ' drift age was estimated using lichenometry to have formed around $0.9+0.0 /-0.1 \mathrm{kyr}$ (Werner 1982). Sample Denali $7(1.6 \pm 0.2 \mathrm{kyr})$, for example, is 0.7 $+0.2 /-0.3 \mathrm{kyr}$ older than the lichen age. This could be inheritance and, as such, may reflect the time of transport of the boulder from bedrock into the landform. Reworking from older lateral moraines seems less likely for these deposits, since the ' $\mathrm{Y}$ ' drift is less extensive and has a lower glacier surface than older deposits. All four of the boulders will likely move again as the ice-core melts and the moraine stabilizes. This amount of inheritance, while significant on an extremely young landform, would be within the noise for older moraine dates.

Only one sample (Denali 10) has a ${ }^{10} \mathrm{Be}$ age $(0.9 \pm 0.2 \mathrm{kyr})$ that overlaps with the lichen age $(0.9$ $+0.0 /-0.1 \mathrm{kyr})$. Determining the history of a singular boulder is difficult, as it can have a complex pre-exposure and exhumation history resulting in a ${ }^{10} \mathrm{Be}$ age of $0.9 \pm 0.2 \mathrm{kyr}$. Owing to the extensive ice-core, this boulder will very likely move or topple before the ' $\mathrm{Y}$ ' drift stabilizes.

Two younger samples (Denali 8 at $0.3 \pm 0.1$ and Denali 9 at $0.4 \pm 0.1 \mathrm{kyr}$ ) have likely moved or been exhumed since deposition. These boulders, along with most of the surface boulders and sediment, will continue to move until the ' $\mathrm{Y}$ ' drift moraine becomes stable. Similar processes and amounts of inheritance and instability must have occurred on the ' $\mathrm{X}$ ' drift. However, boulders on the ' $\mathrm{X}$ ' drift do not show significant inheritance, so the readjustment of boulders during stabilization probably resets the ${ }^{10} \mathrm{Be}$ SED ages.

\section{Active ice}

Boulders on the active ice of Muldrow Glacier have ${ }^{10} \mathrm{Be}$ ages that range from $0.1 \pm 0.2 \mathrm{kyr}$ to $1.9 \pm 0.4 \mathrm{kyr}$ (Fig. 5). Lichen was not present on any of the boulder surfaces. Two of the ${ }^{10} \mathrm{Be}$ ages (Denali $11-13$, at $0.1 \pm 0.2 \mathrm{kyr}$ and $0.3 \pm 0.3 \mathrm{kyr}$ ) are close to zero age, which shows that inheritance of these boulders is minimal. Denali 13 and Denali 14 samples, however, with ages of $0.2 \pm 0.1 \mathrm{kyr}$ and $1.9 \pm 0.4 \mathrm{kyr}$, have minor and significant inheritance, respectively.

\section{Discussion of landform stabilization}

Two of four boulders sampled on the active ice of Muldrow Glacier range from 0.2 to $1.9 \mathrm{kyr}$ and therefore have minor and significant inheritance, respectively. The other two boulders have a zero age. Only one of four boulders sampled on the ' $\mathrm{Y}$ ' drift showed significance inheritance (Denali 7 at $1.6 \pm 0.2 \mathrm{kyr}$ ). None of the seven boulders sampled on the ' $\mathrm{X}$ ' drift had inheritance problems, since all of the ' $\mathrm{X}$ ' drift ${ }^{10} \mathrm{Be}$ ages are well clustered and significantly younger (1.26 $+0.14 /-0.24 \mathrm{kyr}$ ) than the independent lichen age. This suggests that until a moraine reaches early stabilization, boulders continue to topple or are exhumed.

Even though the sample sizes for ${ }^{10} \mathrm{Be}$ ages are small, a trend of decreased inherited boulders from 2 of 4 on active ice to 1 of 4 on unstable deposits (' $Y$ ' drift) to 0 of 7 on stable deposits ('X' drift) supports Briner et al.'s (2005) suggestion that ${ }^{10} \mathrm{Be}$ dating defines the time of early landform stabilization. Fresh boulder surfaces and/or fresh boulders are exposed to effectively reset ${ }^{10} \mathrm{Be}$ ages to zero as boulders topple and/or are exhumed as moraines stabilize. We, therefore, suggest that ice-cored landforms in the central Alaska Range obtain their TCN 'zero age' at the time of early stabilization, several centuries to a millennium after deposition of the landform.

In general, the inheritance of TCNs in boulders does not dominate the range of ages we observe on an individual moraine. However, there are notable instances (Denali 14-15 and Denali 20A) in which inheritance is significant and easily distinguishable through statistical analysis. These results are consistent with the view that the probability of inheritance is small, but TCN ages are significantly influenced by the stability of the landform (Shanahan \& Zreda 2000; Putkonen \& Swanson 2003; Zech et al. 2005; Applegate et al. 2008).

The range of exposure ages on individual moraines reflects how long they take to reach early stabilization. Our data suggest that this is a minimum of $\sim 1.3 \mathrm{kyr}$ after the initial formation in central Alaska. This lagtime could have significant effects on correlations between young ice-cored landforms and climatic records. Boulders on different types of landforms probably take different amounts of time to stabilize. Dortch (2006) 

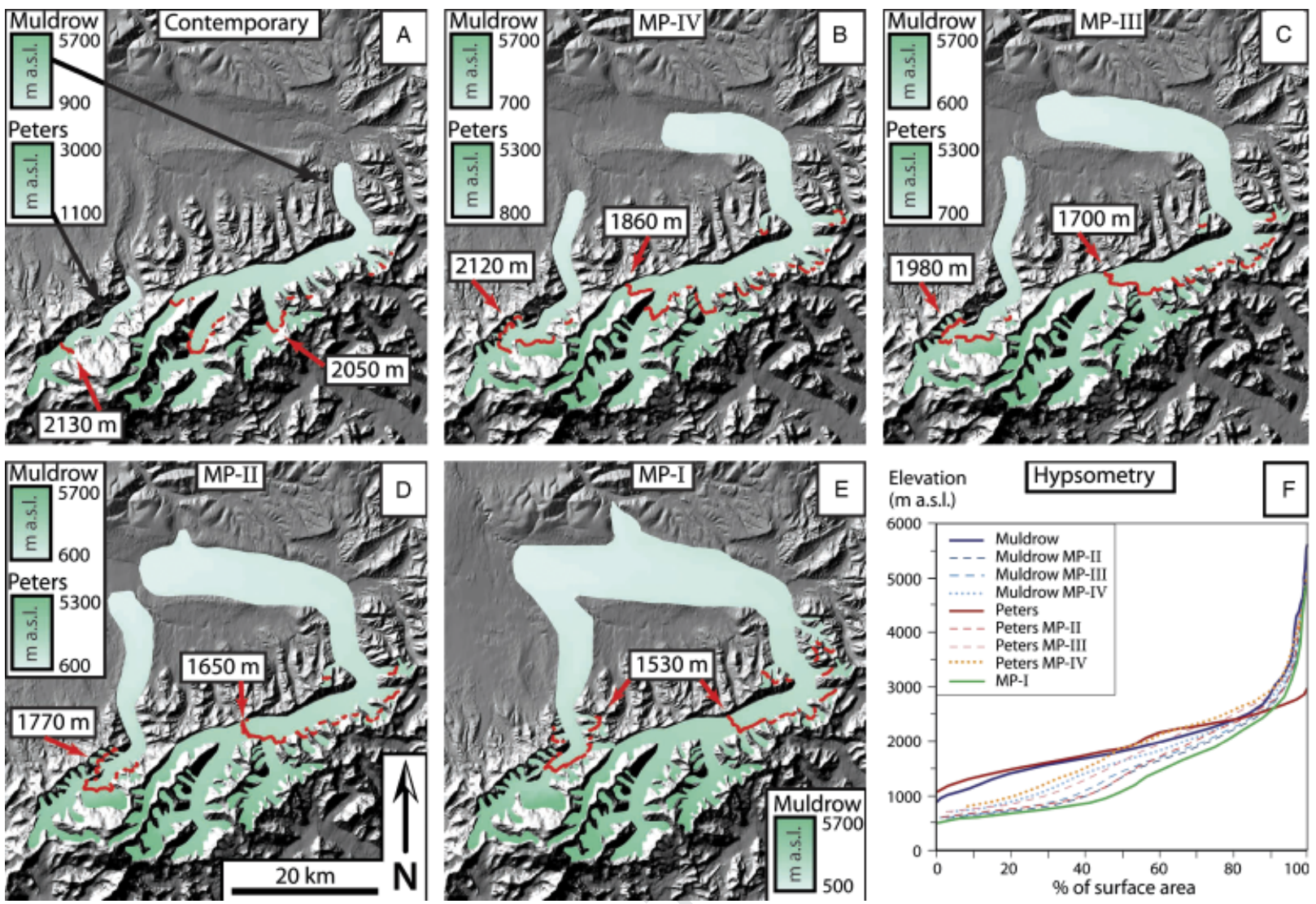

Fig. 6. Shuttle Radar Topography Mission (SRTM) hillshade image showing the reconstructed extent (shown by the thick red line) and calculated ELAs for the Muldrow and Peters glaciers. A. Contemporary extent. B. MP-IV. C. MP-III. D. MP-I. E. MP-I. F. Hypsometry of the Muldrow and Peters glaciers today and for landforms MP-I to MP-IV.

suggested that boulders on drumlins are more stable than boulders inset in till on roche moutonnées, which are more stable than boulders on moraines. A laterofrontal moraine would likely stabilize significantly faster than one of the ice-cored ground moraines sampled in this study (Owen \& Benn 2005). The same moraine would likely stabilize more slowly than a compacted landform such as a drumlin. Therefore, we suggest that caution should be taken when correlating lateHolocene landform surface exposure ages.

\section{Contemporary and former ELAs}

\section{Contemporary ELAs}

Values of contemporary ELAs for the Muldrow and Peters glaciers, determined by different methods, are given in Table 2. The change from convex to concave glacier surface is used as a base because this is determined through direct observation on the glacier trunk of the average of several tributaries. This gives ELA values for the contemporary Muldrow and Peters glaciers of 2000 and $2100 \mathrm{~m}$, respectively. The THAR (0.5) method gives consistently higher values $(\sim 1000 \mathrm{~m})$ than other methods (Table 2) and is probably a function of the glacier hypsometry in this steep topography (Benn \& Lehmkuhl 2000). The AARs (0.5) and (0.6) are consistently $100-600 \mathrm{~m}$ lower than the change from convex to concave glacier surface. Hence, the THAR $(0.5)$ and AARs (0.5 and 0.6) are not used to estimate ELAs.

The AAR (0.4) method gives 2080 and $2250 \mathrm{~m}$ a.s.l. and the AA method 2075 and $2040 \mathrm{~m}$ a.s.l. for the Muldrow and Peters glaciers, respectively. These most closely agree with the values based on the change in surface shape method. Therefore, we report the mean and $1 \sigma$ standard error of these methods for contemporary ELA values for the Muldrow (2050 $\pm 30 \mathrm{~m}$ a.s.l.) and Peters ( $2130 \pm 60 \mathrm{~m}$ a.s.1.) glaciers (Fig. 6A). The $\sim 80 \mathrm{~m}$ lower ELA for Muldrow Glacier is likely the result of the glacier's larger catchment area. The mean and standard deviation are used to calibrate the AABR model to reconstruct former ELA position.

\section{Former ELA reconstruction}

Ratios of 1.1 (Muldrow Glacier) and 0.65 (Peters Glacier) are used to calibrate the AABR model to within $1 \mathrm{~m}$ of the modern ELA value of $2050 \pm 30 \mathrm{~m}$ 
a.s.1. and $2130 \pm 60 \mathrm{~m}$ a.s.1., respectively (Table 2). These AABR calibration ratios were used to model the MP-II, III and IV glacial stage ELAs. Debris-covered glaciers typically yield values of $\sim 1.0$ (Osmaston 2005). The essentially identical contemporary and calibrated AABR model ELAs and the low AABR ratios suggest that the AABR method provides reasonable results.

ELAs for the Muldrow and Peters glaciers were modelled together for the glacial advance that produced the MP-I moraine because the two glaciers were joined during that advance (Thorson 1980). The Muldrow and Peters glaciers likely contributed to the MP-I terminal position disproportionately. In addition, the AABR model weights low and high area more heavily than area near the ELA. To mitigate these problems, we combined the hypsometry of both glaciers and averaged the contemporary AABR ratios (1.1 for Muldrow and 0.65 for Peters) to obtain an AABR ratio (0.875) to represent the combined glacial MP-I system as accurately as possible.

The AABR model is used in conjunction with the AAR (0.4) and AA methods to determine a mean and standard error of former ELAs. Calculated $\triangle$ ELAs are based on the difference between the contemporary mean (change from concave to convex surface of the ice, AAR 0.4 and AA methods) and the former mean (AAR 0.4, AA and AABR methods) and adding errors (Table 2).

\section{Former ELA and $\triangle E L A$ results}

An ELA of $1530 \pm 20 \mathrm{~m}$ a.s.1. based on the MP-I moraine gives a $\triangle$ ELA of $560 \pm 25 \mathrm{~m}$ (Fig. 6B; Table 2). The strong agreement between ELA values based on the AAR (0.4), AA and AABR (0.875 ratio) methods suggests that the ELA reconstruction for this glacial advance at $\sim 28 \mathrm{kyr}$ is accurate.

ELAs for Muldrow Glacier for the MP-II moraine are $1650 \pm 50 \mathrm{~m}$ a.s.l. $(\Delta \mathrm{ELA}=400 \pm 50 \mathrm{~m})$, the MP-III moraine $1700 \pm 50 \mathrm{~m}$ a.s.l. $(\Delta \mathrm{ELA}=350 \pm 60 \mathrm{~m})$ and the MPIV moraine $1860 \pm 40 \mathrm{~m}$ a.s.l. $(\Delta \mathrm{ELA}=190 \pm 50 \mathrm{~m})$ (Fig. 6; Table 2). For the Peters Glacier, ELAs for the MP-II moraine are $1770 \pm 50 \mathrm{~m}$ a.s.l. $(\Delta \mathrm{ELA}=360 \pm 80 \mathrm{~m})$, for the MP-III moraine $1980 \pm 60 \mathrm{~m}$ a.s.l. $(\Delta \mathrm{ELA}=150 \pm$ $90 \mathrm{~m}$ ) and for the MP-IV moraine $2120 \pm 70 \mathrm{~m}$ a.s.l. $(\Delta \mathrm{ELA}=10+90 /-10 \mathrm{~m})($ Fig. 6 ; Table 2$)$. These results are internally consistent, which provides confidence in the values even though the $\triangle$ ELA errors are large.

ELA reconstructions for the Peters Glacier are 100-200 $\mathrm{m}$ higher than those for the Muldrow Glacier. This is consistent with the contemporary ELAs, where the Peters Glacier is $100 \mathrm{~m}$ higher than Muldrow. The MP-II $\triangle$ ELAs for the Muldrow and Peters glaciers are similar. However, the $\triangle$ ELA for the MP-III and MP-IV for Peters Glacier is less than $50 \%$ for Muldrow Glacier and has larger errors $(\sim 90 \mathrm{~m})$. The significantly lower $\triangle E L A$ may be because Muldrow Glacier is more sensitive to climatic change or may be an artefact of the $\triangle E L A s$ for the Peters Glacier having a larger error. However, the contemporary Muldrow Glacier has a more extensive supraglacial debris-cover than the Peters Glacier, which would make it more responsive to precipitation change. Moreover, the Muldrow Glacier's accumulation area extends $\sim 500 \mathrm{~m}$ higher than Peters Glacier, which would increase the orographic effect and thus amplify the precipitation sensitivity of the Muldrow Glacier.

\section{Conclusions}

The late Pleistocene moraines (MP-I to IV) and three late Holocene till deposits (' $\mathrm{X}$ ', ' $\mathrm{Y}$ ' and ' $\mathrm{Z}$ ' drifts) present in the McKinley River region allow assessment of the application of ${ }^{10} \mathrm{Be} \mathrm{TCN}$ dating to define the timing and nature of glaciation and moraine formation and stabilization in central Alaska. The large range of ${ }^{10} \mathrm{Be}$ TCN ages (2.5 to $146 \mathrm{kyr}$ ) for the MP-I moraine highlights the problems of dating late Quaternary moraines in central Alaska. These ages represent a complex preexposure and exhumation history.

Analysis of ${ }^{10} \mathrm{Be}$ ages on active ice and two late Holocene till deposits (active ice (youngest), ' $\mathrm{Y}$ ' drift and ' $\mathrm{X}$ ' drift (oldest)) shows a decrease of inherited boulders from 2 of 4 on the active ice to 1 of 4 on unstable deposits (' $Y$ ' drift) to 0 of 7 on stable deposits (' $X$ ' drift). Until early stabilization is achieved, this suggests that boulders continue to topple or are exhumed. Therefore, sampling active glaciers to define inheritance may not be necessary for ice-cored landforms in the central Alaska Range.

The ' $\mathrm{X}$ ' drift had a weighted mean ${ }^{10} \mathrm{Be}$ age of $0.54 \pm 0.14 \mathrm{kyr}$, but the independent minimum lichen age is $1.8+0.0 /-0.1 \mathrm{kyr}$. The $1.26+0.14 /-0.24 \mathrm{kyr}$ age difference is probably the result of the time-lag between landform deposition (lichen age) and early landform stabilization $\left({ }^{10} \mathrm{Be}\right.$ age). This suggests that early landform stabilization takes more than $1.3 \mathrm{kyr}$ to occur. However, other landforms might stabilize more quickly.

Our study shows that ${ }^{10} \mathrm{Be}$ dating, together with other methods (e.g. radiocarbon dating and lichenometry), can provide an estimate of the timing of early moraine stabilization. When deposition is not equivalent to early stabilization, a correction for ${ }^{10} \mathrm{Be}$ dating is needed. Here, we show this correction to be $\sim 1.3 \mathrm{kyr}$. However, we acknowledge that this is only one study on ice-cored landforms and it may be different in other glacial settings.

Comparisons of ELAs for the Muldrow and Peters glaciers allow assessment of the climatic and topographic controls on glaciation in this region. Contemporary ELAs for the Muldrow and Peters glaciers are 2050 \pm 30 and $2130 \pm 60 \mathrm{~m}$ a.s.l., respectively. $\triangle \mathrm{ELAs}$ for the Muldrow Glacier are $400 \pm 50 \mathrm{~m}$ for MP-II, $350 \pm 60 \mathrm{~m}$ for MP-III and $190 \pm 50 \mathrm{~m}$ for MP-IV moraines; for the Peters Glacier, they are $360 \pm 80 \mathrm{~m}$ for MP-II, $150 \pm 90 \mathrm{~m}$ for MP-III 
and $10+90 /-10 \mathrm{~m}$ for MP-IV moraines. The MP-I glacial stage $\triangle E L A$ for the combined Muldrow and Peters glacial systems is $560 \pm 25 \mathrm{~m}$. The lower $\Delta \mathrm{ELAs}$ for Muldrow Glacier are likely due to the glacier being more sensitive to climatic change. The extensive supraglacial debris-cover probably makes Muldrow Glacier more responsive to changes in precipitation compared to the Peters Glacier. In addition, the $\sim 500 \mathrm{~m}$ higher accumulation area of the Muldrow Glacier would increase the orographic effect and thus amplify its precipitation sensitivity compared to that of the Peters Glacier. The difference in precipitation sensitivity may be responsible for the Muldrow and Peters glaciers oscillating out of phase during the late Holocene.

Our study provides a framework for further examination of the controls and nature of glaciation in central Alaska and an analogue for studies of glaciation using TCN methods in other high mountain regions. Furthermore, it highlights the complexity of applying SED and ELAs in glacial reconstruction.

Acknowledgements. - Thanks to the Murie Science and Learning Center, the Denali National Park and the PRIME Laboratory for funding this project. Thanks, also, to Dr. Lucy Tyrrell for her help with logistics and funding, to Susan Ma for helping calculate our ${ }^{10} \mathrm{Be}$ ages, to the Department of Geology at the University of Cincinnati for GA funding, and to Dr. M. Knudsen and an anonymous reviewer for constructive input that greatly improved the manuscript.

\section{References}

Applegate, P. J. \& Alley, R. B. 2007: A Monte Carlo investigation of inheritance in moraine boulders. Geological Society of America, Abstracts with Programs 39, 142.

Applegate, P. J., Granger, D. E. \& Alley, R. B. 2006: Refining moraine age estimates from cosmogenic exposure dates using the maximum likelihood method. Geological Society of America, Abstracts with Programs 38, 70.

Applegate, P. J., Lowell, T. V. \& Alley, R. B. 2008: Comment on 'Absence of cooling in New Zealand and adjacent ocean during the Younger Dryas chronozone'. Science 320, 746.

Balco, G., Briner, J., Finkel, R. C., Rayburn, J., Ridge, J. C. \& Schaefer, J. M. 2008: Regional beryllium-10 production rate calibration for late-glacial northeastern North America. Quaternary Science Reviews 4, 93-107.

Barrows, T. T., Lehman, S. J., Fifield, L. J. \& Deckker, P. D. 2007: Absence of cooling in New Zealand and adjacent ocean during the Younger Dryas chronozone. Science 318, 86-89.

Barrows, T. T., Lehman, S. J., Fifield, L. J. \& Deckker, P. D. 2008: Response to comment on 'Absence of cooling in New Zealand and adjacent ocean during the Younger Dryas chronozone'. Science $320,746 \mathrm{e}$.

Begét, J. E. 2001: Continuous Late Quaternary proxy climate records from loess in Beringia. Quaternary Science Reviews 20, 499-507.

Begét, J. E. \& Keskinen, M. 1991: The Stampede tephra: A middle Pleistocene marker bed in glacial and eolian deposits of central Alaska. Canadian Journal of Earth Sciences 28, 991-1002.

Begét, J. E. \& Keskinen, M. J. 2003: Trace-element geochemistry of individual glass shards of the Old Crow tephra and the age of the Delta glaciation, central Alaska. Quaternary Research 60, 63-69.

Benn, D. I. \& Lehmkuhl, F. 2000: Mass balance and equilibrium-line altitudes of glaciers in high mountain environments. Quaternary International 65-66, 15-29.
Benn, D. I., Owen, L. A., Osmaston, H. A., Seltzer, G. O., Porter, S. C. \& Mark, B. 2005: Reconstruction of equilibrium-line altitudes for tropical and sub-tropical glaciers. Quaternary International $138-139,8-21$.

Bijkerk, A. 1980: Lichenometry Dating of Neoglacial Deposits in the McKinley Park Area, Alaska. Master's thesis, Grand Valley State Colleges, $54 \mathrm{pp}$.

Briner, J. P. \& Kaufman, D. S. 2008: Late Pleistocene mountain glaciation in Alaska: Key chronologies. Journal of Quaternary Science 23, 659-670.

Briner, J. P., Kaufman, D. S., Manley, W. F., Finkel, R. C. \& Caffee, M. W. 2005: Cosmogenic exposure dating of late Pleistocene moraine stabilization in Alaska. Geologic Society of America Bulletin 117, 1108-1120.

Briner, J. P., Swanson, T. W. \& Caffee, M. W. 2001: Late Pleistocene cosmogenic ${ }^{36} \mathrm{Cl}$ glacial chronology of the southwest Ahklun Mountains, Alaska. Quaternary Research 56, 148-154.

Bull, W. B. \& Brandon, M. T. 1998: Lichen dating of earthquakegenerated regional rockfall events. Southern Alps, New Zealand. Geologic Society of America, Bulletin 110, 60-84.

CalPal-online. 2009: Available at: http://www.calpal-online.de/index. html (accessed 1.01.2009).

Capps, S. R. 1940: Geology of the Alaska railroad region. United States Department of the Interior. Geological Survey Bulletin 907, $1-201$.

CGIAR-CSI, 2007: The CGIAR Consortium for Spatial Information. Available at: http://srtm.csi.cgiar.org/SELECTION/ inputCoord.asp.

Denton, G. \& Karlén, W. 1973a: Lichenometry: Its application to Holocene moraine studies in southern Alaska and Swedish Lapland. Arctic and Alpine Research 5, 347-372.

Denton, G. \& Karlén, W. 1973b: Holocene climatic variations - their pattern and possible cause. Quaternary Research 3, 155-205.

Denton, G. \& Karlén, W. 1977: Holocene glacial treeline variations in the White River Valley and Skolai Pass, Alaska and Yukon Territory. Quaternary Research 7, 63-111.

Dortch, J. M. 2006: Defining the Timing of Glaciation in the Central Alaska Range. Master's thesis, University of Cincinnati, $82 \mathrm{pp}$.

Eberhart-Phillips, D., Haeussler, P. J., Freymueller, J. T., Frankel, A. D., Rubin, C. M., Craw, P., Ratchkovski, N. A., Anderson, G., Carver, G. A., Crone, A. J., Dawson, T. E., Fletcher, H., Hansen, R., Harp, E. L., Harris, R. A., Hill, D. P., Hreinsdóttir, S., Jibson, R. W., Jones, L. M., Kayen, R., Keefer, D. K., Larsen, C. F., Moran, S. C., Personius, S. F., Plafker, G., Sherrod, B., Sieh, K., Sitar, N. \& Wallace, W. K. 2003: The 2002 Denali Fault Earthquake, Alaska: A Large Magnitude, Slip-Partitioned Event. Science 300, 1113-1118.

Fernald, A. T. 1965: Glaciation in the Nebesna River area, upper Tanana River valley, Alaska. U.S. Geological Survey Professional Paper 525-G, C120-C123.

Gosse, J. C. \& Phillips, F. M. 2001: Terrestrial in situ cosmogenic nuclides: Theory and application. Quaternary Science Reviews 20, 1475-1560.

Hallet, B. \& Putkonen, J. 1994: Surface dating of dynamic landforms: Young boulders on aging moraines. Science 265, 937-940.

Hamilton, T. D. 1976: Camp Century $\delta^{18} \mathrm{O}$ record vs. dated climatic records from Alaska and Siberia. Abstracts of the Fourth Biennial Meeting of the American Quaternary Association, vol. 4, 22-24.

Hamilton, T. D. \& Thorson, R. M. 1983: The Cordilleran Ice Sheet in Alaska. In Porter, S. C. (ed.): Late Quaternary Environments of the United States, 38-52. Minneapolis, University of Minnesota Press.

Harrison, A. E. 1969: Glacial activity preceding the 1956 Muldrow Glacier surge in Alaska. Canadian Journal of Earth Sciences 6, $1-1007$.

Harrison, A. E. 1970: Renewed activity of the Muldrow Glacier, Alaska, after the 1956 surge. Journal of Glaciology 9, 397-400.

Ivy-Ochs, S., Kerschner, H., Kubik, P. W. \& Schlüchter, C. 2006: Glacier response in the European Alps to Heinrich event 1 cooling: The Gschnitz stadial. Journal of Quaternary Science 21, 115-130.

Ivy-Ochs, S., Kerschner, H., Reuther, A., Preusser, F., Heine, K., Maisch, M., Kubik, P. W. \& Schlüchter, C. 2008: Chronology of the last glacial cycle in the European Alps. Journal of Quaternary Science 23, 559-573. 
Lal, D. 1991: Cosmic ray labeling of erosion surfaces: In situ nuclide production rates and erosion models. Earth and Planetary Science Letters 104, 424-439.

Matmon, A., Schwartz, D. P., Haeussler, P. J., Finkel, R., Lienkaemper, J. J., Stenner, H. D. \& Dawson, T. E. 2006: Denali fault slip rates and Holocene-late Pleistocene Kinematics of central Alaska. Geological Society of America 34, 645-648.

Mattson, L. E., Gardner, J. S. \& Young, G. J. 1992: Ablation on debris covered glaciers: An example from the Rakhiot Glacier, Punjab. Himalaya. In Snow and Glacier Hydrology, 289-295. Proceedings of the Kathmandu Symposium, November 1992.

McDougall, I. \& Harrison, T. M. 1999: Geochronology and Thermochronology by the 40Ar/39Ar Method. 269 pp. Oxford University Press, Oxford.

Nakawo, M. \& Rana, B. 1999: Estimate of ablation rate of the glacier ice under supraglacial debris layer. Geografiska Annaler 81, 695-701.

Nash, D. B. 2007: ReadArcGrid: Histogram elevations read from datasets in ASCII AcGrid format. Also calculates dimensionless hypsometric curve. Available at: http://homepages.uc.edu/ nashdb/.

Nishiizumi, K., Arnold, J. R., Klein, J., Kohl, C. P., Lal, D., Middleton, R. \& Winterer, E. L. 1989: Cosmic ray production rates of $10 \mathrm{Be}$ and $26 \mathrm{Al}$ in quartz from glacially polished rocks. Journal of Geophysical Research 94, 17907-17915.

Nishiizumi, K., Imamura, M., Caffee, M. W., Southon, J. R., Finkel, R. C. \& McAninch, J. 2007: Absolute calibration of 10Be AMS standards. Nuclear Instruments \& Methods in Physics Research-Beam Interactions with Materials and Atoms 258B, 403-413.

Osmaston, H. 2005: Estimates of glacier equilibrium line altitudes by the Area $\times$ Altitude, the Area $\times$ Altitude Balance Ratio and the Area $\times$ Altitude Balance Index methods and their validation. Quaternary International 138-139, 22-31.

Owen, L. A. \& Benn, D. I. 2005: Equilibrium-line altitudes for the Last Glacial Maximum for the Himalaya and Tibet: An assessment and evaluation of results. Quaternary International 138-139, 55-78.

Owen, L. A., Caffee, M. W., Finkel, R. C. \& Seong, Y. B. 2008: Quaternary glaciation of the Himalayan-Tibetan orogen. Journal of Quaternary Research 23, 513-531.

PRIME (Purdue Rare Isotope Measurement) Laboratory, 2007: PRIME Laboratory rock age calculator. Available at: https:// www.physics.purdue.edu/ams/rosetest/Rkversion1/rockpara.php.

Putkonen, J. \& O'Neil, M. 2005: Degradation of unconsolidated Quaternary landforms in the western North America. Geomorphology 75, 408-419.

Putkonen, J. \& Swanson, T. 2003: Accuracy of cosmogenic ages for moraines. Quaternary Research 59, 255-261.

Putkonen, J., Connolly, J. \& Orloff, T. 2008: Landscape evolution degrades the geologic signature of past glaciations. Geomorphology 97, 208-217.

Rampton, V. N. 1978: Holocene glacial and tree-line variations in the White River valley and Skolai Pass, Alaska and Yukon Territory: A discussion. Quaternary Research 10, 130-134.
Reed, J. C. 1933: The Mount Eielson district, Alaska. U.S. Geological Survey Bulletin 849-D, 231-287.

Reed, J. C. 1961: Geology of the Mt. McKinley Quadrangle, Alaska. U.S. Geological Survey Bulletin 1108-A, 1-36.

Ridgway, K. D., Trop, J. M., Nokleberg, W. J., Davidson, C. M. \& Eastham, K. R. 2002: Mesozoic and Cenozoic tectonics of the eastern and central Alaska Range: Progressive basin development and deformation in a suture zone. Geological Society of America Bulletin 114, 1480-1504.

Shanahan, T. M. \& Zreda, M. 2000: Chronology of Quaternary glaciations in East Africa. Earth and Planetary Science Letters 177, 23-42.

Smith, J. A., Finkel, R. C., Farber, D. L., Rodbell, D. T. \& Seltzer, G. O. 2005: Moraine preservation and boulder erosion in the tropical Andes: Interpreting old surface exposure ages in glaciated valleys. Journal of Quaternary Science 20, 735-758.

Stone, J. O. 2000: Air pressure and cosmogenic isotope production. Journal of Geophysical Research 105(B10), 23753-23760.

Ten Brink, N. W. \& Waythomas, C. F. 1985: Late Wisconsin glacial chronology of the North-Central Alaska Range: A regional synthesis and its implications for early human settlements. National Geographic Research Report 19, 15-33.

Thorson, R. M. 1980: Quaternary glacier expansions from America's highest mountain. Unpublished report.

Thorson, R. M. 1986: Late Cenozoic glaciation of the Nenana valley. In Hamilton, T. D., Reed, K. M. \& Thorson, R. M. (eds.): Glaciation in Alaska - The Geologic Record, 99-121. Alaska Geological Society, Fairbanks.

U.S. Geological Survey. 2007: Available at: agdc.usgs.gov/data/usgs/ erosafo $/ 300 \mathrm{~m} / 300 \mathrm{~m} . \mathrm{html}$.

Wahrhaftig, C. 1958: Quaternary geology of the Nenana River valley and adjacent parts of the Alaska Range. U.S. Geological Survey Professional Paper 293-A, 1-118.

Werner, A. 1982: Glacial Geology of the McKinley River Area, Alaska: with an Evaluation of Various Relative Age Dating Techniques. Master's thesis, Southern Illinois University, $146 \mathrm{pp}$.

Werner, A. \& Child, J. C. 1995: Glacial history of the McKinley River area, Denali National Park and Preserve, Alaska. Abstracts with Programs-Geologic Society of America 27, 83.

Winchester, V. \& Harrison, S. 2000: Dendrochronology and lichenometry: Colonization, growth rates and dating of geomorphological events on the east side of the Northern Patagonian Icefield, Chile. Geomorphology 34, 181-194.

Zech, R., Glaser, B., Sosin, P., Kubik, P. W. \& Zech, W. 2005: Evidence for long-lasting landform surface instability on hummocky moraines in the Pamir mountains (Tajikistan) from ${ }^{10} \mathrm{Be}$ surface exposure dating. Earth and Planetary Science Letters 273, 453-461.

Zreda, M. G. \& Phillips, F. M. 1994: Cosmogenic ${ }^{36} \mathrm{Cl}$ accumulation in unstable landforms 2. Simulations and measurements on eroding moraines. Water Resources Research 30, 3127-3136. 


\section{Author Query Form}

\section{Journal BOR \\ Article 121}

Dear Author,

During the copy-editing of your paper, the following queries arose. Please respond to these by marking up your proofs with the necessary changes/additions. Please write your answers clearly on the query sheet if there is insufficient space on the page proofs. If returning the proof by fax do not write too close to the paper's edge. Please remember that illegible mark-ups may delay publication.

\begin{tabular}{|c|l|c|}
\hline Query No. & \multicolumn{1}{|c|}{ Description } & Author Response \\
\hline Q1 & Author: There is no link for the footnote in Table 1. Please update. & \\
\hline Q2 & $\begin{array}{l}\text { Author: Capps (1932) has been mentioned in the text but not mentioned in the reference list. } \\
\text { Kindly update }\end{array}$ & \\
\hline & & \\
\hline & & \\
\hline & & \\
\hline
\end{tabular}

